\title{
HUBUNGAN JARAK DAN PERMEABILITAS TANAH TERHADAP KADAR TIMBAL (Pb) dan KADMIUM (Cd) AIR SUMUR GALI WARGA DI TPA KALIORI KABUPATEN BANYUMAS
}

\author{
Sulis Aminatul Khoiroh ${ }^{1)}$, Mela Firdaust ${ }^{1)}$, Zaeni Budiono ${ }^{1)}$ \\ Poltekkes Kemenkes Semarang
}

\begin{abstract}
Abstrak
Logam berat yang dihasilkan oleh lindian TPA dapat menjadi salah satu penyebab pencemaran air tanah.Lindian meresap ke dalam tanah dengan mekanisme permeabilitas tanah. Tujuan penelitian ini untuk mengetahui hubungan jarak dan permeabilitas tanah terhadap kadar timbal $(\mathrm{Pb})$ dan kadmium $(\mathrm{Cd})$ air sumur gali warga di sekitar TPA Kaliori. Jenis penelitian ini observasional dengan pendekatan crossectional. Besar sampel sebanyak 15 sumur gali.Hasil penelitian menunjukkan rerata kadar $\mathrm{Pb}$ pada air sumur gali adalah 0 $\mathrm{mg} / 1$ dan rerata kadar Cd air sumur gali $0.000432 \mathrm{mg} / 1$, hasil tersebut berada di bawah nilai ambang batas berdasarkan Permenkes RI Nomor 32 Tahun 2017. Rerata hasil pengukuran jarak sumur gali dengan TPA Kaliori 227,2 meter. Nilai permeabilitas tanah di sekitar kolam lindian 0,123. Nilai permeabilitas tebesar tanah di sekitar sumur gali 14,554 dan terkecil 0,005. Hasil uji statistik dengan menggunakan analisis Regresi Linier Ganda menunjukan bahwa tidak ada hubungan antara jarak dan permeabilitas tanah terhadap kadar timbal $(\mathrm{Pb})$ dan Kadmium $(\mathrm{Cd})$ air sumur gali di sekitar TPA Kaliori ( $p$ value $=0,052$ ). Penelitian disimpulkan tidak ada hubungan antara jarak dan permeabilitas tanah terhadap kadar timbal $(\mathrm{Pb}) \mathrm{dan}$ kadmium (Cd) air sumur gali di sekitar TPA Kaliori. Sebaiknya warga Desa Kaliori menggunakan air PDAM sebagai alternatif sumber air bersih selain sumur gali.
\end{abstract}

Kata kunci: Timbal, Kadmium, Permebailitas, TPA

\begin{abstract}
Heavy metals produced by landfill leaching can be one of the causes of groundwater pollution. Leaching permeated the soil with a soil permeability mechanism. The aims of this research was to determine the correlation of distance and soil permeability to lead and cadmium dug well water around the Kaliori disposal.Design of this research is observational with cross-sectional approaches. The sample dug wells of research are 15 samples. The results of the research showed the average lead level in the dug well water was $0 \mathrm{mg} / \mathrm{l}$ and the cadmium dug water had an average of $0.000432 \mathrm{mg} / \mathrm{l}$, It was still below the threshold value according to the Republic of Indonesia Minister of Health Regulation Number 32 Year 2017. The average of distance dug well with the Kaliori disposal was 227.2 meters. The permeability value of the soil around the leach pond is 0.123. The highest permeability value of the soil around the dug well is 14,554 and the lowest is 0,005. Statistical results using the analysis of Multiple Linear Regression show that there is no correlation between distance and soil permeability against lead and cadmium water in dug wells around the Kaliori disposal ( $p$ value $=0.052$ ). The conclusion of this research was there is no correlation between distance and soil permeability to lead and cadmium levels of dug well water around the Kaliori disposal. It is better for residents of Kaliori Village to use PDAM water as an alternative source of clean water besides dug wells.
\end{abstract}

Keywords: Lead, Cadmium, Permeability, Disposal 


\section{Pendahuluan}

Peraturan Pemerintah Nomor 82 Tahun 2001 tentang Pengelolaan Kualitas Air Dan Pengendalian Pencemaran Air menyebutkan, air merupakan sumber daya alam yang memenuhi hajat hidup orang banyak sehingga perlu dilindungi agar dapat tetap bermanfaat bagi hidup dan kehidupan manusia serta makhluk hidup lainnya. Menurut Peraturan Menteri Kesehatan Republik Indonesia No.32 Tahun 2017 tentang Standar Baku Mutu Kesehatan Lingkungan Dan Persyaratan Kesehatan Air Untuk Keperluan Higiene Sanitasi, Kolam Renang, Solus Per Aqua, Dan Pemandian Umum, air untuk keperluan higiene sanitasi harus dalam keadaan terlindung dari binatang pembawa penyakit, tempat perkembangbiakan vektor, dan sumber pencemaran.

Pencemaran dapat terjadi di perairan, tanah, dan udara. Pencemaran yang paling berbahaya bagi kehidupan manusia adalah pencemaran yang terjadi di perairan. Pencemaran dapat disebabkan oleh zat organik dan zat anorganik berupa logam berat (Manik dalam penelitian Irfandi, 2013). Logam-logam tersebut diketahui dapat terakumulasi di dalam tubuh suatu organisme dan tetap tinggal dalam tubuh dalam jangka waktu yang lama sebagai racun. Dua macam logam berat yang sering mengkontaminasi air adalah timbal dan kadmium (Kristianto dalam penelitian Irfandi, 2013).

Pencemaran oleh logam berat kadmium (Cd) juga pernah diteliti di Jepang. Sumber pencemarnya adalah industri pengolahan timah dan limbahnya masuk ke Sungai Jintsu yang menyebabkan kerusakan pada ginjal yang disebut penyakit Itai-Itai (Nogawa dkk, 2011). Keberadaan logam-logam berat dalam badan perairan berasal dari sumber-sumber alamiah dan aktivitas manusia. Sumber-sumber logam alamiah berupa pengikisan dari batu mineral yang terdapat di sekitar perairan. Logam yang berasal dari aktivitas manusia berupa buangan limbah industri, limbah domestik, penggunaan pupuk yang berlebihan dan lindian TPA (Widaningrum, 2007, dalam penelitian Putri).

Tempat Pemrosesan Sampah (TPA) yang dimiliki Pemerintah Kabupaten Banyumas adalah TPA Kaliori. TPA Kaliori terletak di Desa Kaliori, Kecamatan Kalibagor. TPA ini beroperasi sejak tahun 1993 dan memiliki luas area $\pm 5,4$ ha. TPA Kaliori dijadikan Tempat Pemrosesan Akhir (TPA) sampah yang bersifat padat maupun cair untuk menampung sampah yang dihasilkan wilayah Purwokerto dan sekitarnya. Sampah tersebut berasal dari permukiman, perniagaan, perkantoran, pelayanan kesehatan dan instansi lainnya.
Sampah yang dibuang ke TPA Kaliori belum diklasifikasikan berdasarkan jenis organik dan anorganik.

Berdasarkan survei pendahuluan volume sampah yang dibuang ke TPA Kaliori sebanyak $406,73 \mathrm{~m}^{3} /$ hari. Sebanyak 227,77 $\mathrm{m}^{3}(56 \%)$ adalah sampah organik. Pada hari senin, 02 April 2018 sekitar seratus warga RW 03 Desa Kaliori, Banyumas berdemonstrasi di kawasan TPA Kaliori. Mereka menuntut agar pengelola TPA memperbaiki pengelolaan sampah karena TPA Kaliori kelebihan muatan. Dalam aksi damai tersebut, ratusan warga membentangkan spanduk dan poster berisi tuntutan. Mereka meminta agar pengelola TPA mengembalikan kondisi Kaliori yang bersih dan tidak lagi tercemar. Setelah kejadian tersebut pembuangan sampah ke TPA Kaliori dibatasi menjadi $130 \mathrm{~m}^{3} /$ hari.

Permukiman warga RW 03 dan RW 04 berjarak 150 meter dari TPA Kaliori. Sedangkan RW lain (01, 02, 05, 06, 07, dan 08) berjarak $1,5 \mathrm{~km}$ dari TPA Kaliori, sehingga permukiman terdekat dengan TPA Kaliori memiliki kemungkinan besar tercemar lindian. TPA Kaliori berada pada ketinggian 85 mdpl kemudian berangsur turun ke arah selatan menjadi $20 \mathrm{mdpl}$ wilayah permukiman yang berdekatan dengan Sungai Serayu. Jenis tanah Desa Kaliori yaitu Podsolik Merah Kuning dan Latosol yang memiliki permeabilitas lambat hingga sedang (Bappeda Kabupaten Banyumas). Rerata hasil pemeriksaan kadar $\mathrm{Pb}$ pada 3 sampel air sumur gali warga di sekitar TPA Kaliori yaitu sumur 1 (jarak $\pm 100 \mathrm{~m}$ ), sumur 2 (jarak $\pm 135 \mathrm{~m}$ ), dan sumur 3 (jarak $\pm 110 \mathrm{~m}$ ) masing-masing 0,061 mg/l, 0,052 $\mathrm{mg} / \mathrm{l}$, dan $0,047 \mathrm{mg} / \mathrm{l}$. Kadar $\mathrm{Pb}$ pada sumur 1 dan sumur 2 melebihi baku mutu $\mathrm{Pb}$ berdasarkan Peraturan Menteri Kesehatan Republik Indonesia No. 32 Tahun 2017 yaitu 0,05 mg/l (Choeroel Anwar dkk, 2018).

Tujuan penelitian adalah mengetahui hubungan jarak dan permeabilitas tanah terhadap kadar timbal $(\mathrm{Pb})$ dan kadmium $(\mathrm{Cd})$ air sumur gali warga di sekitar TPA Kaliori

\section{Bahan dan Metode}

Jenis penelitian ini adalah observasional dengan pendekatan analitik cross-sectional untuk mengetahui ada tidaknya hubungan antara jarak dan permeabilitas tanah terhadap kadar timbal $(\mathrm{Pb})$ dan kadmium $(\mathrm{Cd})$ air sumur gali warga di sekitar TPA Kaliori, Kecamatan Kalibagor, Kabupaten Banyumas. Logam berat timbal dan kadmium dalam sampel air sumur gali dianalisis di laboratorium Balai Besar Teknik Kesehatan Lingkungan dan Pengendalian Penyakit (BBTKLPP) 
Yogyakarta menggunakan alat Atomic Absorption Spektrofotometer (AAS). Permeabilitas tanah diperiksa di laboratorium tanah Universitas Jenderal Soedirman menggunakan metode ring sampel.

Tabel 3.1 Hasil Perhitungan Jarak Sumur Gali ke TPA Kaliori

\begin{tabular}{ccc}
\hline No. & Sampel & Jarak $(\mathrm{m})$ \\
\hline 1. & S1 & 24 \\
\hline 2. & S2 & 135 \\
\hline 3. & S3 & 147 \\
\hline 4. & S4 & 168 \\
\hline 5. & S5 & 191 \\
\hline 6. & S6 & 218 \\
\hline 7. & S7 & 231 \\
\hline 8. & S8 & 260 \\
\hline 9. & S9 & 277 \\
\hline 10. & S10 & 288 \\
\hline 11. & S11 & 289 \\
\hline 12. & S12 & 290 \\
\hline 13. & S13 & 295 \\
\hline 14. & S14 & 295 \\
\hline 15. & S15 & 300 \\
\hline
\end{tabular}

Penelitian dilaksanakan pada bulan Desember 2018-Februari 2019.Populasi sumur gali adalah seluruh sumur gali yang ada di Desa Kaliori, sedangkan sampel adalah sumur gali yang berada pada radius 300 meter dari TPA Kaliori.Besar sampel yang diambil adalah 15 sampel.Jarak sumur gali dengan TPA Kaliori diukur dengan global positioning system (GPS).

Instrument penelitian merupakan alat untuk mengumpulkan data penelitian.Instrument penelitian yang digunakan dalam penelitian ini adalah lembar penjelasan penelitian, lembar persetujuan, alat AAS, botol timba, botol sampel, dan kuesioner.

Sampel air sumur diambil pada lokasi yang telah ditentukan dan dimasukkan dalam botol plastik $500 \mathrm{ml}$, sampel dikirimkan ke laboratorium menggunakan ice box. Sampel tanah diambil menggunakan ring sampel di lokasi penelitian, kemudian dibawa ke laboratorium untuk dilakukan pemeriksaan. Data hasil pengukuran jarak, permeabilitas tanah, logam berat timbal dan kadmium diolah secara univariat. Hubungan jarak dengan kadar timbal, jarak dengan kadar kadmium, permeabilitas tanah dengan timbal, permeabilitas tanah dengan kadmium diuji dengan Regresi Linier Ganda, serta hubungan jarak dan permeabilitas tanah terhadap kadar timbal dan kadmium air sumur gali menggunakan uji Regresi Linier Berganda.

\section{Hasil dan Pembahasan}

a. Univariat

1. Pengukuran Jarak sumur gali

Pedoman jarak aman untuk memanfaatan air tanah di sekitar TPA tidak diatur secara spesifik. Untuk menghindari terjadinya kontaminasi bahan yang bersifat kimia, maka penggalian sumur yang dimanfaatkan untuk keperluan higyene sanitasi atau air minum dapat dilakuan pada radius > 300 meter. Hal ini dikarenakan batas cemaran bahan yang bersifat kimia memiliki jarak 300 meter dari wilayah terluar TPA berdasarkan Peraturan Menteri Pekerjaan Umum Nomor 19/PRT/M/2012 tentang Pedoman Penataan Ruang Kawasan Sekitar Tempat Pemrosesan Akhir (TPA) sampah.

Menurut Peraturan Menteri Pekerjaan Umum Nomor 19/PRT/M/2012 tentang Pedoman Penataan Ruang Kawasan Sekitar Tempat Pemrosesan Akhir (TPA) sampah, untuk TPA yang menerapkan sistem controlled landfill dan sanitary landfill kawasan sekitar TPA dibagi menjadi subzone penyangga dan subzone budidaya terbatas. Kawasan subzone terbatas berfungsi untuk melindungi penduduk yang melakukan kegiatan sehari-hari di sekitar TPA Kaliori, mencegah lindian masuk ke dalam mata air dan badan air yang berdampak terhadap kesehatan masyarakat, mencegah vektor seperti lalat dan tikus merambah kawasan permukiman, dan menyerap debu yang berterbangan. Kawasan ini berjarak 0-500 meter diukur dari kawasan terluar TPA.

a. Angka Permeabilitas Tanah di Sekitar Kolam Lindian

Sampel tanah yang digunakan untuk pengukuran permeabilitas tanah kolam lindian diambil pada radius $100 \mathrm{~cm}$ sebelah selatan dari kolam lindian. Sampel diambil di tanah bagian atas (top soil) pada hari Selasa, 12 Februari 2019 Pukul 07.23 WIB dengan kondisi tidak terjadi hujan pada hari tersebut dan satu hari sebelumnya. Hasil pengukuran permeabilitas tanah di sekitar kolam lindian menghasilkan nilai 0,123 , menurut Uhland and O'neal nilai tersebut termasuk permeabilitas sangat lambat.

Tabel 3.2 Hasil Permeabilitas Tanah di Sekitar Kolam Lindian.

\begin{tabular}{ccc}
\hline $\begin{array}{c}\text { Kode } \\
\text { Sampel }\end{array}$ & $\begin{array}{c}\text { Angka } \\
\text { Permeabilitas }\end{array}$ & Keterangan \\
\hline S0 & 0,123 & Sangat lambat \\
\hline
\end{tabular}


Laju permeabilitas yang lambat menurunan potensi lindian TPA Kaliori mencemari badan air atau air tanah yang ada di sekitarnya, karena semakin berkurang kemampuan melewatkan air yang berarti jumlah bahan pencemar yang dapat bergerak mengikuti aliran tanah semakin sedikit. (Nugroho Wahyu Prasetyo, 2012).Kolam lindian TPA Kaliori sudah tidak berfungsi sebagaimana mestinya dikarenakan adanya longsoran sampah yang menutup sebanyak 30 kolam. Lindian yang mengandung berbagai bahan organik dan anorganik salah satunya yaitu logam berat yang seharusnya tertampung dan mengalami proses penguraian menjadi tidak terproses dengan baik, sehingga kualitas lindian pada outlet tidak jauh beda dengan lindian pada inlet.

Lindian merembes masuk ke tanah dapat mengakibatan penurunan kualitas air tanah dan sungai. Apabila air tersebut digunakan untuk keperluan sehari-hari seperti memasak, mencuci, mandi maka akan berbahaya bagi kesehatan manusia. Tidak hanya itu, luapan lindian yang mencemari lahan pertanian dapat terakumulasi di dalam tanaman yang ada pada lahan tersebut. Apabila tanaman dikonsumsi oleh manusia maka konsestrasi logam berat dalam tubuh akan bertambah sebagai efek dari proses bioakumulasi. Keadaan ini jika terus menerus berlangsung maka konsentrasi logam berat ( $\mathrm{Cd}$ dan $\mathrm{Pb}$ ) yang melebihi ambang batas dapat menyebabkan penyakit berbahaya misalnya kanker, ginjal, dan beberapa penyakit lain (Eko Siswoyo, dkk. 2018. H 3-4).

b. Angka Permeabilitas di Sekitar Sumur
Gali
Hasil perhitungan angka permebailitas tanah menunjukkan hasil yang bervariasi, dari nilai paling kecil (S9) yaitu 0,005 dengan kategori sangat lambat hingga nilai 14,554 (S15) dengan kategori cepat. Pengambilan sampel tanah dilakukan dengan metode ring sampel untuk mengambil sampel tanah utuh.

Tabel 3.3 Angka Permeabilitas di Sekitar Sumur Gali

\begin{tabular}{ccl}
\hline Kode Sampel & $\begin{array}{c}\text { Angka } \\
\text { Permeabilitas }\end{array}$ & Keterangan \\
\hline S1 & 0,009 & Sangat lambat \\
\hline S2 & 0,052 & Sangat lambat \\
\hline S3 & 0,132 & Lambat \\
\hline S4 & 0,047 & Sangat lambat \\
\hline S5 & 0,044 & Sangat lambat \\
\hline S6 & 0,942 & Agak lambat \\
\hline S7 & 0,220 & Lambat \\
\hline S8 & 0,052 & Sangat lambat \\
\hline S9 & 0,005 & Sangat lambat
\end{tabular}

\begin{tabular}{ccl}
\hline Kode Sampel & $\begin{array}{c}\text { Angka } \\
\text { Permeabilitas }\end{array}$ & Keterangan \\
\hline S10 & 0,061 & Sangat lambat \\
\hline S11 & 0,045 & Sangat lambat \\
\hline S12 & 0,049 & Sangat lambat \\
\hline S13 & 4,529 & Sedang \\
\hline S14 & 13,009 & Cepat \\
\hline S15 & 14,554 & Cepat \\
\hline \multicolumn{2}{c}{ Jenis tanah di lokasi pengambilan sampel }
\end{tabular}
adalah Podsolik Merah Kuning, berdasarkan laporan akhir Bapedda Banyumas tahun 2017 seharusnya tanah ini memiliki nilai permeabilitas lambat sampai sedang. Sedangkan pada sampel S14 dan S15 nilai permeabilitasnya cepat. Hal ini dikarenakan pada saat pengambilan sampel S14 dan S15, sampel yang berada pada ring sampel kurang padat sehingga terdapat banyak rongga, hal lain yang dapat mempengaruhi nilai permeabilitas ini adalah peneliti kurang tepat menempatkan ring sampel pada tanah sehingga terdapat bebatuan atau kerikil pada sampel tanah yang ada pada ring sampel, sehingga pada saat dilakukan uji permeabilitas, rongga/ bebatuan tersebut masih dapat meloloskan air.

\section{c. Kadar Logam Berat Timbal $(\mathrm{Pb})$ Air Sumur Gali}

Berdasarkan hasil pemeriksaan pada 15 air sampel sumur gali di Desa Kaliori semua sampel mengandung $0 \mathrm{mg} / 1$ kadar $\mathrm{Pb}$. Kadar tersebut masih memenuhi standar baku mutu persyaratan $\mathrm{Pb}$ (timbal) pada Permenkes No.32 Tahun 2017 tentang Standar Baku Mutu Kesehatan Lingkungan Dan Persyaratan Kesehatan Air Untuk Keperluan Higiene Sanitasi , Kolam Renang, Solus Per Aqua, dan Pemandian Umum sebesar 0,05 mg/ 1.

Tabel 3.4 Hasil Pengukuran Logam Berat Pb (Timbal) Air Sumur Gali Desa Kaliori

\begin{tabular}{|c|c|c|}
\hline \multicolumn{3}{|c|}{ Kadar Logam } \\
\hline $\begin{array}{c}\text { Kode } \\
\text { Sampel }\end{array}$ & $\begin{array}{c}\text { Berat } \\
\mathrm{Pb} \text { (Timbal) } \\
(\mathrm{mg} / \mathrm{l})\end{array}$ & Keterangan \\
\hline $\mathrm{S} 1$ & 0 & \multirow{15}{*}{$\begin{array}{c}\text { Memenuhi } \\
\text { Syarat }\end{array}$} \\
\hline $\mathrm{S} 2$ & 0 & \\
\hline $\mathrm{S} 3$ & 0 & \\
\hline $\mathrm{S} 4$ & 0 & \\
\hline S5 & 0 & \\
\hline S6 & 0 & \\
\hline S7 & 0 & \\
\hline S8 & 0 & \\
\hline S9 & 0 & \\
\hline S10 & 0 & \\
\hline S11 & 0 & \\
\hline S12 & 0 & \\
\hline S13 & 0 & \\
\hline S14 & 0 & \\
\hline S15 & 0 & \\
\hline
\end{tabular}


Pengambilan sampel dilakukan pada 17 Desember 2019 (musim penghujan).Kadar $\mathrm{Pb}$ yang tidak ada dimungkinkan karena terjadi pengenceran lindian dan air sumur oleh air hujan.Pemeriksaan sampel dilakukan menggunakan AAS (Atomic Absorbtion Spectrofotometri) dengan metode garnit furnice. Metode ini dinilai lebih presisi untuk memeriksa sampel dengan ketelitian $<0,01 \mathrm{mg} /$ 1. Jenis tanah pada lokasi penelitian adalah Podsolik Merah Kuning (tanah liat), pada penelitian Cindy (2014) tanah liat dapat mereduksi atau menyerap logam berat $\mathrm{Pb}$ sebanyak $61 \%$.

Pada penelitian yang dilakukan oleh Choeroel Anwar dkk pada tahun 2018 hasil pemeriksaan kadar Pb pada 3 sampel air sumur gali warga di sekitar TPA Kaliori yaitu sumur 1 (jarak $\pm 100 \mathrm{~m})$, sumur 2 (jarak $\pm 135 \mathrm{~m})$, dan sumur 3 (jarak $\pm 110 \mathrm{~m}$ ) masing-masing 0,061 $\mathrm{mg} / \mathrm{l}, 0,052 \mathrm{mg} / \mathrm{l}$, dan 0,047 mg/l. Kadar $\mathrm{Pb}$ pada sumur 1 dan sumur 2 melebihi baku mutu $\mathrm{Pb}$. Hal ini berbanding terbalik dengan hasil yang diperoleh pada penelitian ini. Perbedaan ini dikarenakan beberapa faktor yaitu, pengambilan sampel penelitian dilakukan pada musim kemarau, sehingga tidak ada pengenceran dan pemeriksaan logam beratnya menggunakan alat spektrofotometer.

Pada penelitian yang dilakukan oleh Suyanta dan Siti Kholifah (2016) mengenai perbandingan hasil analisis ion logam Ca dalam sampel air kolam renang dengan tehnik AAS dan Spektrofotometer didapatkan bahwa hasil penelitian menunjukkan ada perbedaan hasil analisis konsentrasi ion logam $\mathrm{Ca}$ dalam air kolam renang yaitu Spektrofotometer sebesar 45,61 ppm, sedangkan pada AAS sebesar 0,87 ppm.

\section{d. Kadar Logam Berat Kadmium (Cd) Air Sumur Gali}

Hasil pengukuran logam berat $\mathrm{Cd}$ (kadmium) air sumur gali Desa Kaliori, kadar Cd tertinggi berada pada S1 dengan nilai 0,0008736 mg/l dan kadar Cd terendah berada pada S7 dengan nilai $0,0000455 \mathrm{mg} / 1$. Kadar tersebut masih memenuhi standar baku mutu persyaratan Cd (kadmium) pada Permenkes No.32 Tahun 2017 tentang Standar Baku Mutu Kesehatan Lingkungan Dan Persyaratan Kesehatan Air Untuk Keperluan Higiene Sanitasi , Kolam Renang, Solus Per Aqua, dan Pemandian Umum sebesar 0,005 mg/ 1 .

Faktor yang memperngaruhi kadar $\mathrm{Cd}$ pada air sumur maupun badan air yaitu pengambilan sampel dilakukan pada 17 Desember 2018 (musim penghujan), sehingga pengenceran air sampel oleh air hujan membuat konsentrasi $\mathrm{Cd}$ pada air sumur menjadi lebih rendah dibandingkan dengan musim kemarau ( Eko Siswoyo, dkk. 2018. h 3-4). Jenis tanah Desa Kaliori adalah Podsolik Merah Kuning atau tanah liat. Berdasarkan tabel 2.6 tentang kemampuan absorban berbagai media terhadap logam berat, pada penelitian yang dilakukan oleh Atina Khairat dkk (2013) jenis tanah liat/ NAPA dapat mereduksi/ mengurangi logam berat Cd sebesar 68,72\%.

Tabel 3.5 Hasil Pengukuran Logam Berat Cd (Kadmium) Air Sumur Gali Desa Kaliori

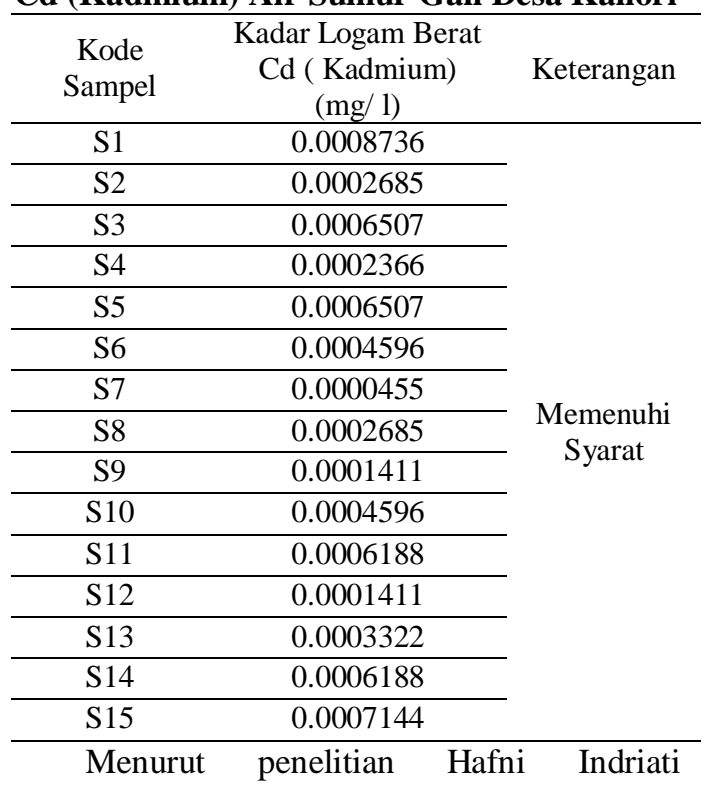

Nasution ( 2017 ) dalam perjalanan mencapai lapisan-lapisan tanah dengan ukuran pori -pori bermacam-macam maka kadar $\mathrm{Cd}$ akan terabsorbsi oleh jenis tanah pada lokasi tersebut, sehingga mengakibatkan konsentrasi logam berat Cd dalam sumur akan lebih kecil. Hasil pemeriksaan menunjukkan adanya penurunan kadar $\mathrm{Cd}$ dari sampel $\mathrm{S} 1$ sampai $\mathrm{S} 15$, namum pada beberapa titik kadar $\mathrm{Cd}$ mengalami kenaikan dari titik sebelumnya. Sebagai contoh pada sampel S8 pada jarak 260 $\mathrm{m}$ dari TPA kadar Cd mengalami kenaikan dari titik S7. Hal ini dimungkinkan sumber Cd tidak hanya berasal dari lindian TPA. Sumber pencemar lain dimungkinkan berasal dari limbah B3 rumah tangga yang tidak diolah dengan benar, seperti pembuangan aki, batu baterai, bohlam lampu, dan korek api. Sehingga perlu dilakukan penelitian lebih lanjut mengenai pengolahan limbah B3 rumah tangga ini.

\section{b. Bivariat}

1. Hubungan jarak sumur gali dengan kadar kadmium $(\mathrm{Cd})$

Hasil analisis hubungan jarak sumur gali dengan kadar kadmium (Cd) air sumur gali di 
sekitar TPA Kaliori Desa Kaliori memiliki nilai $p$ value sebesar 0,043 . Karena $p<0,05$, maka korelasi antara jarak sumur gali ke TPA dengan kadar $\mathrm{Cd}$ air sumur gali signifikan atau dengan kata lain ada pengaruh antara jarak sumur gali ke TPA terhadap kadar $\mathrm{Cd}$ air sumur gali. Koefisien beta sebesar -0,559 menunjukkan hubungan negatif, yang berarti semakin jauh jarak sumur gali ke TPA maka semakin kecil kadar Cd pada air sumur gali.

Tabel 3.6 Hubungan Jarak Sumur Gali Dengan Kadar Kadmium (Cd) Air Sumur Gali

\begin{tabular}{lcc}
\hline \multicolumn{1}{c}{ Variabel } & Signifikan & B \\
\hline $\begin{array}{l}\text { Jarak sumur gali } \\
\text { dengan kadar kadmium } \\
\text { (Cd) }\end{array}$ & 0,043 & - \\
\hline
\end{tabular}

Penelitian yang dilakukan oleh Dwi
Anggriana (2011) Hasil analisis menunjukan adanya hubungan jarak dengan kadar logam yang terkandung, dimana semakin dekat jarak sumur dengan tempat pengolahan limbah maka kadar logam berat yang terkandung dalam air sumur tersebut juga semakin besar. Logam berat meresap ke tanah dalam keadaan jenuh, semakin banyak kadar pencemar yang terkandung dalam limbah, semakin besar pula kemungkinan limbah tersebut mencemari air. Dalam perjalanannya melewati lapisan tanah, dengan adanya jarak maka partikel-partikel bahan pencemar terabsorpsi jenis tanah di lokasi penelitian, sehingga pada jarak tertentu kadar pencemar akan berkurang. Hasil penelitian menunjukkan kadar $\mathrm{Pb}$ pada jarak 50 $\mathrm{m}$ dari sumber pencemar $1,27 \mathrm{mg} / \mathrm{L}$, kemudian mengalami penurunan $70,86 \%$ menjadi 0,37 $\mathrm{mg} / \mathrm{l}$ pada jarak $100 \mathrm{~m}$, dan pada jarak $150 \mathrm{~m}$ mengalami penurunan $2,7 \%$ menjadi $0,36 \mathrm{mg} / \mathrm{l}$.

2. Hubungan permeabilitas tanah dengan kadar kadmium $(\mathrm{Cd})$

Hasil analisis hubungan jarak sumur gali dengan kadar kadmium (Cd) air sumur gali di sekitar TPA Kaliori Desa Kaliori memiliki nilai $p$ value sebesar 0,035. Karena $p<0,05$ maka korelasi antara angka permeabilitas tanah sumur gali terhadap kadar $\mathrm{Cd}$ air sumur gali signifikan atau dengan kata lain ada pengaruh antara angka permeabilitas tanah sumur gali terhadap kadar $\mathrm{Cd}$ air sumur gali. Koefisien beta sebesar 0,589 menunjukkan hubungan positif, yang berarti semakin besar angka permeabilitas tanah maka semakin besar kadar $\mathrm{Cd}$ pada air sumur gali.

\begin{tabular}{|c|c|c|}
\hline \multicolumn{3}{|c|}{$\begin{array}{l}\text { Tabel 3.7 Hubungan Permeabilitas Tanah } \\
\text { dengan Kadar Kadmium (Cd) Air Sumur } \\
\text { Gali Desa Kaliori }\end{array}$} \\
\hline Variabel & Signifikan & B \\
\hline $\begin{array}{l}\text { Permeabilitas tanah } \\
\text { dengan kadar kadmium } \\
\text { (Cd) }\end{array}$ & 0,035 & 0,589 \\
\hline
\end{tabular}

Permeabilitas tanah adalah kemampuan tanah untuk mengalirkan air ke lapisan dibawahnya.Nilai permeabilitas tergantung pada jenis tanah. Secara teoritis pengukuran nilai permeabilitas untuk jenis tanah yang sama, maka akan menghasilkan nilai permeabilitas dalam rentang angka yang sama. Data hasil penelitian menunjukkan semakin jauh jarak sumur gali ke TPA, nilai permeabilitasnya semakin besar, tetapi nilai permeabilitas tidak dipengaruhi oleh jarak. Permeabilitas tanah sangat dipengaruhi oleh karakteristik pori terutama kestabilan pori yang ditentukan oleh kestabilan agregat tanahnya (Masria dkk, 2017). Sehingga yang mempengaruhi kadar logam berat dalam air bukanlah permeabilitas, tetapi karakteristik pori pada tanah yang menentukan jenis tanah pada suatu tempat.

Pada uji statistik terdapat hubungan antara permeabilitas tanah dengan kadar logam berat kadmium (Cd) pada air sumur, hal tersebut dikarenakan pada sampel S14 dan S15 nilai permeabilitasnya besar (cepat) dan hasil pemeriksaan kadmium (Cd) pada sampel S14 dan S15 juga berangsur naik, sehingga secara perhitungan statistik menghasilkan perhitungan yang signifikan atau memiliki hubungan. Sedangkan seharusnya nilai permeabilitas tanah lempung di lokasi penelitian berada pada rentang sangat lambat-sedang.

\section{c. Multivariat}

Hasil analisis hubungan jarak dan permeabilitas tanah terhadap kadar kadmium (Cd) air sumur gali di sekitar TPA Kaliori memiliki tingkat signifikan koefisiensi korelasi $(p)$ sebesar 0,052. Nilai $\mathrm{p}>0,05$ artinya nilai $p$ tidak signifikan sehingga $\mathrm{Ha}$ ditolak, tidak ada hubungan antara jarak sumur gali ke TPA dan angka permeabilitas tanah sumur gali terhadap kadar $\mathrm{Cd}$ di air sumur gali.

Hasil penelitian Taufik Ashar dkk (2013) bahwa tidak ada korelasi jarak sumur gali ke TPA dengan konsentrasi krom, timbal, maupun merkuri dalam air sumur gali.Pada penelitian tersebut peneliti memeriksa 68 sampel air sumur yang dipilih secara acak.Setelah dilakukan analisis didapatkan nilai $p$ masing untuk krom, timbal, dan 
merkuri masing- masing 0,184, 0,268, dan 0,222 . Pada penelitian lain di TPA Banyurip, Kabupaten Magelang, Jawa Tengah menunjukkan bahwa hubungan jarak sumur gali ke TPA dengan kandungan mangan dan besi dalam air sumur gali milik warga tidak signifikan. Ini berarti jarak sumur gali dengan TPA dengan radius 500-1000 meter tidak mempengaruhi kandungan logam-logam berat dalam air tanah pada lokasi tersebut (Yuliati Y dalam penelitian Taufik Ashar dkk. 2013).

\section{Simpulan}

Tidak ada hubungan antara jarak dan permeabilitas tanah terhadap kadar timbal $(\mathrm{Pb})$ dan kadmium $(\mathrm{Cd})$ pada air sumur gali di sekitar TPA Kaliori dengan nilai $\mathrm{p}$ sebesar 0,052 .

\section{Daftar Pustaka}

Ahmad Irfandi, dkk. 2013. Analisis Kandungan Kadmium (Cd) Dan Timbal (Pb) Pada Air Sumur Gali Penduduk Di Sekitar Industri Daur Ulang Aki Dan Gangguan Kesehatan Pada Masyarakat Desa Bandar Khalipah Kabupaten Deli Serdang Tahun 2013. Skripsi. Palembang : Universitas Sumatera Utara. www.repository.usu.ac.iddiakses pada 23 Oktober 2018 pukul 18.34.

Bangun Ismansyah. 2010. Kriteria Teknis TPA Sampah. Jurnal Teknik Lingkungan : 2-5. Jayapura : Universitas Sains Dan Teknologi Jayapura. www.eprints.uny.ac.iddiakses pada 20 Oktober 2018 pukul 23.05.

Bima Yudhyarto, dkk. 2015. Pengaruh Tempat Pembuangan Akhir Sampah Putri Cempo Surakarta Terhadap Kualitas Air Tanah Dangkal Penduduk Sekitar. e-Jurnal Matriks Teknik Sipil. Hal 564-569. Universitas Sebelas Maret : Surakarta. https://digilib.uns.ac.iddiakses pada 24 Oktober 2018 pukul 20.45.

Buddin A. Hakim. 2016. Studi Awal Potensi Limbah Cair Sampah (Lindi) Sebagai Sumber Energi Alternatif Biogas Di Tempat Pembuangan Akhir (TPA) Keputih Surabaya. Magister Ilmu Lingkungan Konsentrasi Rekayasa Lingkungan. Semarang : Universitas Diponegoro. www.mil.undip.ac.iddiakses pada 01 Oktober 2018 pukul 20.00.
Cindy. 2014. Adsorpsi Logam Seng Dan Timbal Pada Limbah Cair Industri Keramik Oleh Limbah Tanah Liat. Jurnal Reaktor. 15(1): 10-19. Depok: Universitas Indonesia. www.lib.ui.ac.iddiakses pada 29 November 2018 pukul 20.34.

Cut Khairunnisa, 2012. Pengaruh Jarak dan Konstruksi Sumur Serta Tindakan Pengguna Air terhadap Jumlah Koliform Air Sumur Gali Penduduk di Sekitar Pasar Hewan Desa Cempeudak Kecamatan Tanah Jambo Aye Kabupaten Aceh Utara Tahun 2012. Thesis. Ilmu Kesehatan Masyarkat. Medan : Universitas Sumatera Utara. www.repository.usu.ac.iddiakses pada 17 November 2018 pukul 21.54.

Eko Siswoyo, Ghozi Faiz Habibi. 2018. Sebaran Logam Berat Kadmium (Cd) dan Timbal (Pb) pada Air Sungai dan Sumur di Daerah Sekitar Tempat Pembuangan Akhir (TPA) Wukisari Gunung Kidul, Yogyakarta. Jurnal Pengelolaan Sumber Daya Alam dan Lingkungan. 8(1) : 1-6. Jurusan Teknik Lingkungan: Universitas Islam Indonesia. www.journal.ipb.ac.iddiakses pada 18 Oktober 2018 pukul 20.35.

Erna A Rakhmawati. 2016. Kajian Pengelolaan Air Lindi (leachate) di Lingkungan Tempat Pembuangan Akhir (TPA) Putri Cempo Surakarta Berbasis Kemanfaatan. Jurnal Ekosains. 7(4) : 8-15. Universitas Sebelas Maret : Surakarta. https://digilib.uns.ac.iddiakses pada 18 oktober 2018 pukul 20.56 .

Heryando Palar. 1994. Pencemaran dan Toksikologi Logam Berat. Jakarta: Rineka Cipta.

Indonesia, Menteri Kesehatan Republik Indonesia. 2017. Peraturan Menteri Kesehatan Republik Indonesia No.32 Tahun 2017 tentang Standar Baku Mutu Kesehatan Lingkungan Dan Persyaratan Kesehatan Air Untuk Keperluan Higiene Sanitasi, Kolam Renang, Solus Per Aqua, Dan Pemandian Umum. Jakarta : Kementrian Kesehatan Republik Indonesia.

Irhamni, dkk. 2017. Kandungan Logam Berat pada Air Lindi Tempat Pembuangan Akhir (TPA) Sampah Kota Banda Aceh. Prosiding Seminar Nasional Pascasarjana (SNP) Unsyiah, A19-A22. Banda Aceh : Indonesia. 
Janti Marchela Sari. 2012. Pengelolaan Sampah Di TPA Piyungan Sebagai Sumber Belajar dalam Bentuk Modul Pengayaan Materi Pelestarian Lingkungan bagi Siswa SMA Kelas X Semester II. Skripsi. Yogyakarta : Program Studi Pendidikan Biologi. www.eprints.uny.ac.iddiakses pada 20 Oktober pukul 21.10

Soekidjo Notoatmodjo. 2011. Kesehatan Masyarakat Ilmu dan Seni. Jakarta : Rineka Cipta.

M. Choeroel A, dkk. Analisis Jalur Pajanan Logam Berat $(\mathrm{Pb})$ Pada Sedimen Aliran Sungai Tempat Pembuangan Akhir (TPA) Kaliori Kabupaten Banyumas. Riset Unggulan Poltekkes Semarang : Semarang.

Munawar Ali. 2011. Rembesan Air Lindi (leachate) Dampak Pada Tanaman Pangan dan Kesehatan. Surabaya: UPN PRESS

Nugroho Wahyu Prasetyo. 2012. Kualitas Air Tanah Di Sekitar Tempat Pembuangan Akhir (TPA) Sampah Banjaran Desa Banjaran Kecamatan Bojongsari Kabupaten Purbalingga. Skripsi. Pendidikan Geografi. Purwokerto: Universitas Muhammadiyah Purwokerto

Resti Nanda Sari, Afdal. 2017. Karakteristik Air Lindi (Leachate) di Tempat Pembuangan Akhir Sampah Air Dingin Kota Padang. Jurnal Fisika Unand. 6 (1):93-99. Jurusan Fisika. Padang : Universitas Andalas. www.jfu.fmipa.unand.ac.iddiakses pada 12 Oktober 2018 pukul 19.34
SIti Maro'ah. 2011. Kajian Laju Infiltrasi dan Permeabilitas Tanah Pada Beberapa Model Tanaman. Skripsi. Surakarta : Universitas Sebelas Maret. www.digilib.uns.ac.iddiakses pada 29 Oktober 2018 pukul 19.30.

Siti Sulastri, dkk. 2004. Sifat Adsorptif Terhadap Ion Kromium. Prociding. Yogyakarya : Universitas Negeri Yogyakarta. www.staff.uny.ac.iddiakses pada 29 November 2018 pukul 20.11.

Suyanta, Siti Kholifah. 2016. Perbandingan Hasil Analisis Ion Logam Ca Dalam Sampel Air Kolam Renang Dengan Tehnik AAS Dan ICP Aes. Paper Semnas Kimia. www.staffnew.uny.ac.iddiakses pada 02 Mei 2019 pukul 19.45.

Taufik Ashar, dkk. 2013. Kromium, Timbal, dan Merkuri dalam Air Sumur Masyarakat di Sekitar Tempat Pembuangan Akhir Sampah. Jurnal Kesehatan Masyarakat Nasional. 7(9) : 408-414. Fakultas Kesehatan Masyarakat : Universitas SumateraUtara.

Titin Agustina. 2014. Kontaminasi Logam Berat Pada Makanan Dan Dampaknya Pada Kesehatan. Jurnal Teknobuga. 1(1) : 5365. https://journal.unnes.ac.iddiakses pada 28 Oktober 2018 pukul 20.45

Tri Cahyono. 2018. Pedoman Penulisan Proposal Penelitian dan Karya Tulis Ilmiah atau skripsi. Purwokerto: Kementerian Kesehatan RI Politeknik Kesehatan Depkes Semarang Jurusan Kesehatan Lingkungan. 